\title{
MASCULINISM IN NOVEL FIFTY SHADES OF GREY: A CULTURAL STUDY
}

\author{
Danar Cristanto \\ Department of English Teaching \\ Faculty of Letters and Arts Education IKIP PGRI Madiun
}

\begin{abstract}
In the modern age, there are many media to serve entertainment. One of the media is novel. Novel is the object material for this research study. This research analyzes about masculinism in Novel Fifty Shades of Grey. It analyzes focus in masculinism that happen in American Culture related Novel Fifty Shades of Grey. The aim of this research is to analyze the existence of masculinism in American Culture. A Cultural Study is chosen by the researcher in order to analyze the research problems.

The research method applied is descriptive qualitative research and popular literature theory. The source of the data are taken from Novel Fifty Shades of Grey, books, articles, webs, and journals that related with the analysis of the masculinism in American Culture as study of culture. The technique of collecting data is by using document technique. The techniques of analyzing data are content or document analysis.

Fifty Shades of Grey is a romance novel that contains complicated relationship between main characters. The plot of masculinism novel always makes a man has more power toward woman. The popularity of masculinism novel is influenced by masculinism practice in the Culture. Masculinism in modern age still exists in society in difference ways that masculinism is exist in American Culture by the peoples think, make and do. The purposes of the masculinism practices are not only to show care, interest and loves but alsoforce man's desire and isolate their woman from public. This research uses theory of masculinism which masculinism is a system of interrelated social structures which allow men to exploit women. The result of the research is masculinism still exist in American Culture.
\end{abstract}

Keywords: Masculinism, Cultural Study

\section{Introduction}

Novel Fifty Shades of Grey tells love between a man and a woman from different social class, their relationship is quite complicated. Christian Grey as the character has his own rule in that relationship. $\mathrm{He}$ makes contract that they have to agree by each other. The contract explains about the rule and the way they build their relationship.
There are two sides in the contract, first is the man who likes to dominate the woman which is called as the dominant, second the woman that is dominated by the man is called submissive. As written in the contract he has total authority and can do everything as he want the woman, he can give rules to the woman that she has to obey, otherwise she will get physical punishment.It makes the 
woman cannot be free from the man.The relationship between the man and the woman lead to the practice of masculinism.

Fifty Shades of Grey is popular literature, which can be seen from the achievement and selling record. It is supported by Ida Rochani Adi (2010: 33)"This thing can be seen from reader opinion or viewer in the world that also can be seen from the selling record". First, according to an article in hypable.comentitled "Fifty Shades sells 100 million copies, joining Potter and Twilight in achievement" that written by Andrew Sims, the novel gets best selling book that sold over 100 million copies. An article inyourtango.com entitled "4 Reasons Why '50 Shades' Is Still So popular" that is written by Kali Williams, writes 4 reasons why Fifty Shades of Grey is very popular. First reason is because the economy, in these economically uncertain times and the fantasy of having someone ridiculously wealthy in "Your Life is Sexy" and practical for both men and women, it encourage the reader to imagine the content of the novel their life. Second because it is Anti-Cosmo, coming from a world full of Cosmopolitan magazine - which focuses almost exclusively on satisfying male pleasure - it's nice to see a story that has a lot of interest in female pleasure. Third because it is easy toread, there has been a lot said about how the book was written but the bottom line is the book is very easy to read.

As popular culture product, the novel consists of masculinism practice that related closely to the culture. It means that a literary work may speak about culture and it is known as Cultural Study of Literature. It has correlation with the event or change in culture; it can be politic, religion, family, class social or state. It is supported by Gans (1974: 11) in his book says "Cultural products cannot exist far from the society who create and use it". It means that a novel as cultural product is made based on culture in society. One of the cultures is masculinism such as how a man treats a woman.

The researcher assumes that a literary work is the reflection of culture as in the novel Fifty Shades of Grey which shows practices of masculinism where the power is pursued by dominating the woman. It influences the culture relation between people and culture.The researcher takes this research by using culturalism approach or known as cultural study of literature. To investigate, the cultural study of literature need an appropriate approach. Theories of cultural study by Ida Rochani Adi and Herbert J. Gansare the appropriate tools to answer the research problems. It is how a system and the existence of masculinism in America culture. Thus, that penomenon makes the researcher is curious in doing 
research entitled Masculinism in Fifty Shades of Grey.

\section{Masculinism}

Masculinism as ideology is the opposite of Feminism. Feminism believes that woman should have the same rights and opportunities as men. Meanwhile, masculinism is an ideology which believes that a man has higher rights and opportunities than woman. Mary Anne Borelli and Janet M. Martin in their book entitled The Other Elites (1997), say masculinism is a better name than patriarchy for the political ideology that structures current arrangements. Masculinism fits within the "structure of gender as ideology and myth," in which gender as ideology is relatively autonomous and hegemonic and is reinforce through and elaborate system of rules and punishment. It means that masculinism and patriarchy have same meaning. According to Walby, patriarchy is "a system of interrelated social structures which allow men to exploit women" (Aprilia A. Gordon, 1996: 18). So, masculinism can be defined when men are allowed to exploit women.

Masculinism appears because Masculinist and Feminist have different view. Feminist thinks that a woman has right same as a man, then masculinist argue about this idea. In the beginning of 19 century, a French philosopher E. Belford Bax in his book The Fraud of Feminism (1913) writes the dominance of men seemed to derive so obviously from natural causes, from the possession of faculties physical, moral and intellectual, in men, which were wanting in women that no one thought of questioning the situation. It means there is discrepancy between masculinist and feminist. Bax assumes that woman cannot replace the role of a man physically, morally and intellectually because he thinks that a man and woman have many differences.

The characteristics of masculinity itself from time to time always changes, it is supported by Ida Rochani Adi (2010: 183) "The representation of masculinity from physical appearance of main character in the American movies or novel always changes time to time. The characteristics of main character is not same as old masculinity which a masculinist has big body, strong tall, ride a horse alone and fight against villain but the characteristics of masculinity in the modern age is different, it looks like modern character like Brad Pitt, Tom Cruise, etc. and in the modern age, the body shape no longer become important part but thin and healthy body become choices".

Masculinism is not only shown by race and physic but also character attitude and behavior, it is supported by Ida Rochani Adi who says "the third category which not to be significant in change of imaging masculinity is the behavior or attitude of 
main character to woman. A main character no longer represented as someone who strong to keep his masculinity identity by the manner of him to keep distance with woman, but it represented by normal people that has love and interest to woman"(2010: 187), it is not significant change because it is no represented by appearance as race and physic which shown by appearance.

\section{Cultural Study}

Cultural Study is "An approach that emphasize opinion that by analyzing culture in the society like the kind of written texts and cultural practices that documented, we probably can find explanation about the deed pattern and constellation ideas that exist between the peoples that produces, consumes text and the practices in the society" (Ida Rochani Adi, 2010: 199). It means that Cultural Studies is a study about popular literature that is related with culture, so literature has close correlation with culture, literature is produced by idea from the people that does the culture then consumed by society.

\section{Method}

The researcher uses qualitative method to analyze and to get information about masculinism in Fifty Shades of Grey because the researcher analyzes about phenomenon in American Culture. Qualitative method is the method that appropriate with this analysis because masculinism is part of society or human problem. It supported by "Qualitative research is a means for exploring and understanding the meaning individuals or groups ascribe to a social or human problem" (Creswell, 2009:4). Additionally Creswell (2009: 16)"also says "in this situation, the researcher seeks to establish the meaning of a phenomenon from the views of participants. It means identifying a culture-sharing group and studying how it develops shared patterns of behavior over time". Sothe correlation between the topic masculinism as a phenomenon in culture and qualitative research can be described by exploring and undestanding the phenomenon from the views of participants as the member of society by studying how it develops shared patterns of behavior overtime which is related to culture or human problem. Thus, the researcher uses qualitative method to analyze the novel Fifty Shades of Grey.

The researcher has to search the data. The data must have correlation with the problem which will be analyzed in next chapter. Through the data, the researcher gets some information to be interpreted and makes the conclusion. The data is every event that shows masculinism practice in the novel. There are two kinds of data. They are primary and secondary data which is the primary data is taken from Novel Fifty Shades of Grey and secondary data is taken from article, journal, etc. 
The collecting data technique, the researcher uses documentation method. Techniques of documentation are refference, abstract guides, and content analysis (Kothari, 2004:7). Then documentation is hand-recorded note from the literary (Creswell, 2012 : 214). It means that the documentation method analyzes about text. So, the researcher uses documentation as data collection technique to analyze about masculinism which is reflected in the novel Fifty Shades of Grey.

To analyze the data, the researcher needs technique which appropriate to the data. According to Ary, Jacobs, Razavieh, Sorensen (2010: 29) "content analysis focuses on analyzing and interpreting recorded material to learn about human behavior. The material may be public records, textbooks, letters, films, tapes, diaries, themes, reports, or other documents". So, the researcher use a novel entitled Fifty Shades of Grey by E. L. James as the material that contains of human behavior.

To analyze the data, the researcher uses cultural study because masculinism has close relation with culture in society. This theory is about correlation between culture and literature which literature, like the novel whichusually becomes potrait of the condition in the culture. It is clear that it has correlation with culture which studies about culture such as masculinism phenomenon in American Culture related in the novel.

The researcher will solve the problem which become research questions as explained before. . In the second chapter, the researcher will analyze about masculinism practice in the novel. The researcher describes about what is masculinism that is reflected by Christian Grey in Fifty Shades of Greyrelated American culture. So, it can answer to the question about masculinism itself. Then in the third chapter, the researcher will analyze about how it practices in culture which is reflected in Fifty Shades of Grey by using theory of Cultural Study of Literature by Ida Rochani Adi. So, it can be understood how literature has correlation with culture through masculinism then finds the existence of masculinismin American culture.

\section{Discussion}

The researcher found the existence of masculinism in novel Fifty Shades of Grey that the masculinism can be the appearance, behavior, habit, mindset, attitude of main character, it supported by statement "a main character in the American popular literature usually also has certain attitude, a main character usually express their entire behavior that they have by act not words (Ida Rochani Adi, 2010: 184)". Then there are characteristics of masculinity that represented by normal people that has love 
and interest to woman, it is supported by "the third category which not to be significant in change of imaging masculinity is the attitude or behavior of main character to woman. A main character no longer represented as someone who strong to keep his masculinity identity by the manner of him to keep distance with woman, but it represented by normal people that has love and interest to woman"(Ida Rochani Adi, 2010: 187) which is the first category is about appearance and second category is about behavior of main character. The masculinism also expressed as exploitation to the woman, it is related with theory "a system of interrelated social structures which allow men to exploit women" (Aprilia A. Gordon, 1996: 18). So, there are three things which researcher found about masculinism related with the theories, those are the behavior of masculinist, characteristics of masculinist and exploitation in masculinism.

\section{The Behavior of Masculinist}

There are many similarity events about masculinism practice in second chapter, so the researcher would compile it into become one.

Double crap - me and my two left feet! I am on my hands and knees in the doorway to Mr. Grey's office, and gentle hands are around me helping me to stand. I am so embarrassed, damn my clumsiness. I have to steel myself to glance up. Holy cow - he's so young.

"Miss Kavanagh." He extends a longfingered hand to me once I'm upright. "I'm Christian Grey. Are you all right? Would you like to sit?" (James, E.L, 2011:10)

The event above show the behavior of masculinist when Grey offers help for a woman that in trouble by lend a hand to help her stand up.

"Mr. Grey." I nod at him. Moving with lithe athletic grace to the door, he opens it wide. "Just ensuring you make it through the door, Miss Steele." He gives me a small smile. (James, E.L, 2011:10)

The quotation above show the behavior of masculinist when Christian Grey opens the door for her to ensuring she make through the door.

"He's carrying a tray, which he sets down on the small, round, birch-veneer table. He hands me a cup and saucer, a small teapot, and a side plate bearing a lone teabag labeled 'Twinings English Breakfast' - my favorite. He has a coffee which bears a wonderful leaf-pattern imprinted in the milk. How do they do that? I wonder idly. He's also bought himself a blueberry muffin. Putting the tray aside, he sits opposite me and crosses his long legs" (James, E.L, 2011:33)

The events above show behavior of masculinist while Grey ask her for join coffee with him, he serve the menu for her in the table. 
"Shit, Ana!" Grey cries. He tugs the hand that he's holding so hard that I fall back against him just as a cyclist whips past, narrowly missing me, heading the wrong way up this one-way street."

(James, E.L, 2011:36)

The event above contains the behavior of masculinist when Grey pulls Ana into his side in order to save her while she runs to the wrong one way street.

Those events above represent the theory that says "a main character in the American popular literature usually also has certain behavior, a main character usually express their entire behavior that they have by act not words" (Ida Rochani Adi, 2010: 184). So, the purposes of those events are showing the behavior of Christian Grey that he cares about her.

The behavior of Christian Grey represent the behavior of a masculinist as a man who is better on visual-spatial cognitive task, it is supported by "boys do better on visual-spatial task such as the ability to rotate a three-dimensional figure or the rod and frame test (Marchbank, 2007: 118). It means the reason of Christian Grey does those behavior because he is as a man that is better on spatial task. he cares, interests and loves with her.

Based on those events above the researcher would like to find same events in society that has same purpose about men awareness behavior toward women, the behavior which researcher mean will be taken from daily activity of society which is form of culture because culture is people do, it is like a man that give a seat to the women in the train, helping a woman walking across the street and carrying a woman's item which is heavy. Then, the researcher will look from many aspects.

According to psychological theory of gender, "boys do better on visual-spatial task such as the ability to rotate a threedimensional figure or the rod and frame test (Marchbank, 2007: 118)". The events above much related with physical activity. So, this theory in the practice on society is much related with behavior of masculinity because a man that has better on spatial task should give a help to a woman in order to show his awareness to her as represented by events in the novel and practices in daily activity on society as culture.

According to social scope "Women in the main have lesser power than men, and some men have less power than others therefore, analyses based around materiality and patriarchy remain useful (Marchbank, 2007 :19)". The power that theory means can be right, opportunity or role in society. So, it means men who have higher power than women should give awareness to women who have less power than him, the awareness can be by his behavior as represented by events in the novel and practices in daily activity on society as culture. 
Behavior of Christian Grey really exists in society. It is represented by daily activity on society like a man that give a seat to the women in the train, helping a woman walking across the street and carrying a woman's item which is heavy. The researcher found two reason that make he does the behavior, those are psychology and social. According to psychologycal theory, a man has better on spatial task rather than woman, so he should care to woman that has not . Then according to social theory, a woman has less power than him, the power researcher mean is right and opportunity in social life, so he should care to woman that has not. This explanation is foundation of every behavior of masculinist that happens in culture.

\section{The Characteristics of Masculinist}

Then, the further events explain the other practice masculinism in society that show the characteristic of masculinist related with theory "the third category which is not to be significant in change of imaging masculinity is the behavior or attitude of main character to woman. A main character no longer represented as someone who strong to keep his masculinity identity by the manner of him to keep distance with woman, but it represented by normal people that has love and interest to woman"(Ida Rochani Adi, 2010: 187), the events below shown the main character characteristics toward women which explain if he interests with her. As quotations below:

"Err... yes, I came with both. Christian, please, I need to tell Kate. She'll worry." His mouth presses into a hard line, and he sighs heavily.

"If you must."

He sets me down, and, taking my hand, leads me back into the bar. I feel weak, still drunk, embarrassed, exhausted, mortified, and on some strange level absolutely off the scale thrilled. He's clutching my hand - such a confusing array of emotions. I'll need at least a week to process them all"

(James, E.L, 2011:47)

The event above show characteristics of masculinist when Christian Grey sets her down and taking her hand to lead her back into the bar to tell Kate.

"Ready to go?"

I nod. I wonder what his conversation was about. He slips on a navy pinstriped jacket, picks up his car keys, and heads for the door.

"After you, Miss Steele," he murmurs, opening the door for me. He looks so casually elegant.

(James, E.L, 2011:57)

The event above show characteristics of masculinist when Christian Grey picks up his car key and opening the door for her.

Those event above represent theory of characteristics masculinist, Christian Grey acts in the events above does not keep distance toward her but he serve her instead in order to show his feeling about her that he 
is interested in loves with her. So, it means Christian Grey has characteristics of masculinist that represented by his act toward her.

Those events need to be proved if really exist in society as culture characteristics of masculinity that is living in society. It is included on human behavior. Then, researcher would like to take events based on news, article and research that happen in society.

There is an article in www.financesonline.com entitled "10 Most Expensive and Eccentric Celebrity Gifts: Jessica Simpson \& Adam Sandler Top the List" is telling about birthday gift for their beloved people. Russell Brand is husband of American singer Katy Perry who gives a trip to space which worth around $\$ 100,000$, and then Kanye West who is American singer gives 10 Burger Kings to his wife Kim Kardashian.

According to an article entitled "The Construction of Masculinity: A CrossCultural Analysis of Men's Lifestyle Magazine Advertisements" that is written by Yue Tan, Ping Shaw, Hong Cheng, Kwangmi Ko Kim which the subjects are magazine in Taiwan, China, and the United States to examine the representations of masculinity in their advertisements between 2008 and 2010, then they found there are four masculinity type (2013: 239): a. Vigorous and Macho.

Tough and Macho with a traditional cowboyish look and temperament, the model is muscular in physique and determined in facial expression. The sharp, angular lines of his face speak of toughness and resolution. With tanned skin, in leather or cowboy clothes, the model appears - in either expression or posture-nomadically unkempt, strong-willed and lion-hearted.

Vigorous and Sunny like a boy next door, the model often wears a coy, innocent, and brilliant smile. His skin is tanned. His clothing is sporty and casual. His look and posture are those of someone who is amiable and easy-going.

b. Refined and Sophisticated.

Refined and gentle with the look of a well-learned intellectual, the model appears cultured, polite, graceful, and goodmannered. He is often dressed in preppy style (e.g. shirts, argyle sweaters, etc) and wears glasses. His hair is always neat and tidy, and his appearance is always clean and classic.

Stern and Sophisticated with a confident and firm look, the model impresses the viewers as mature and reliable. $\mathrm{He}$ is dressed in formal attire (usually suits). He is a man of some age, with wrinkles upon his face. His gaze is focused. He is often a man with a successful career.

c. Trendy and Cool. 
Trendy and Cool, Clothed and accessorized in the latest fashion, the model is likely to stand in a provocative posture and displays a freedom-loving and rebellious temperament. His facial expression is either numb or aloof, thereby creating a sense of distance between him and his viewers. He often leers at people and assumes the attitude of indifference and scorn.

d. Other.

Sensual and Sexy, often in sexually arousing attire or revealing, tight clothes such as swimming suit and underwear, the model usually looks away from the camera and refrains from appearing smart and sophisticated or springy and sunny. His facial expression and posture-such as caressing his own body_often seem.

Androgynous with exquisite features, the model dresses and behaves in a more feminine way or wears make up. He appears in a more delicate, meek, and dependent posture.

The researcher finds the relation between primary and secondary data, the relation is in the primary data where Christian Grey does not keep distance and does everything for her in order to show his feeling to her, it has relation or similarity with secondary data that same as celebrities does in order to show their loves to their couple. Christian Grey is included on masculinity type $B$ that is Refined and
Sophisticated because he has good manner to woman. Christian Grey and celebrities do those act because they are the representation of the way they support and express their feeling to their couple.It is supported by "close relationship always need each other.

This close relationship shown by understanding and balanced feedback, there is condition giving and accepting psychologycal or social support, and feel comfortable when near or interact with couple (Fattah Hanurawan, 2010: 163). So, the events above exist in society as culture which is represented by secondary data.

\section{The Exploitation in Masculinism.}

Then, the last theory of masculinism that needs to be proved as culture in society is "a system of interrelated social structures which allow men to exploit women" (Aprilia A. Gordon, 1996: 18). According to the theory, the event happen because someone has relationship with the other and they have conflict that provoke them to do exploitation, the exploitation can be physically or psychologically, It is also described in the novel as events below:

\section{RULES}

\section{Obedience:}

The Submissive will obey any instructions given by the Dominant immediately without hesitation or reservation and in an expeditious manner. The Submissive will 
agree to any sexual activity deemed fit and pleasurable by the Dominant excepting those activities which are outlined in hard limits (Appendix 2). She will do so eagerly and without hesitation.

Sleep:

The Submissive will ensure she achieves a minimum of seven hours sleep a night when she is not with the Dominant.

Food:

The Submissive will eat regularly to maintain her health and wellbeing from a prescribed list of foods (Appendix 4). The Submissive will not snack between meals, with the exception of fruit.

\section{Clothes:}

During the Term, the Submissive will wear clothing only approved by the Dominant. The Dominant will provide a clothing budget for the Submissive, which the Submissive shall utilize. The Dominant shall accompany the Submissive to purchase clothing on an ad hoc basis. If the Dominant so requires, the Submissive shall during the Term any adornments the Dominant shall require, in the presence of the Dominant and any other time the Dominant deems fit.

\section{Exercise:}

The Dominant shall provide the Submissive with a personal trainer four times a week in hour-long sessions at times to be mutually agreed between the personal trainer and the Submissive. The personal trainer will report to the Dominant on the Submissive's progress.

\section{Personal Hygiene/Beauty:}

The Submissive will keep herself clean and shaved and/or waxed at all times. The Submissive will visit a beauty salon of the Dominant's choosing at times to be decided by the Dominant, and undergo whatever treatments the Dominant sees fit.

\section{Personal Safety:}

The Submissive will not drink to excess, smoke, take recreational drugs, or put herself in any unnecessary danger.

\section{Personal Qualities:}

The Submissive will not enter into any sexual relations with anyone other than the Dominant. The Submissive will conduct herself in a respectful and modest manner at all times. She must recognize that her behavior is a direct reflection on the Dominant. She shall be held accountable for any misdeeds, wrongdoings, and misbehavior committed when not in the presence of the Dominant.

Failure to comply with any of the above will result in immediate punishment, the nature of which shall be determined by the Dominant. 
(James, E.L, 2011:76)

The rules above represents exploitation of masculinism, it is shown by almost everything on submissive has been managed by the dominant, such as The Submissive will agree to any sexual activity deemed fit and pleasurable by the Dominant excepting those activities which are outlined in hard limits and the Submissive will wear clothing only approved by the Dominant.

He sighs and runs his hands through his hair again.

"It's the way I'm made, Anastasia. I need to control you. I need you to behave in a certain way, and if you don't - I love to watch your beautiful alabaster skin pink and warm up under my hands. It turns me on."Holy shit. Now we're getting somewhere.

"So it's not the pain you're putting me through?"

He swallows.

"A bit, to see if you can take it, but that's not the whole reason. It's the fact that you are mine to do with as I see fit - ultimate control over someone else. And it turns me on. Big time, Anastasia. Look, I'm not explaining myself very well... I've never had to before. I've not really thought about this in any great depth. I've always been with likeminded people," he shrugs apologetically. "And you still haven't answered my question - how did you feel afterwards?"

(James, E.L, 2011:200)

The event above shows psychology exploitation.It is shown by Christian Grey when he said if "you are mine to do with as I see fit - ultimate control over someone else.
It means he really control and takes her freedom.

He opens the door, and still grasping my arm, grabs what looks like a belt from the rack beside the door, then leads me over to the red leather bench in the far corner of the room.

"Bend over the bench," he murmurs softly.

Okay. I can do this. I bend over the smooth soft leather. He's left my bathrobe on. In a quiet part of my brain, I'm vaguely surprised that he hasn't made me take it off. Holy fuck this is going to hurt... I know. My subconscious has passed out, and my inner goddess is endeavoring to look brave.

"We're here because you said yes, Anastasia. And you ran from me. I am going to hit you six times, and you will count with me."

Why the hell doesn't he just get on with it? He always makes such a meal of punishing me. I roll my eyes, knowing full well he can't see me.

He lifts the hem of my bathrobe, and for some reason, this feels more intimate than being naked. He gently caresses my behind, running his warm hand all over both cheeks and down to the tops of my thighs.

"I am doing this so that you remember not to run from me, and as exciting as it is, I never want you to run from me," he whispers.

And the irony is not lost on me. I was running to avoid this. If he'd opened his arms, I'd run to him, not away from him.

"And you rolled your eyes at me. You know how I feel about that." Suddenly, it's gone - that nervous edgy fear in his voice. He's back from wherever he's been. I hear it in his tone, in the way he places his fingers on my back, holding me - and the atmosphere in the room changes. 
I close my eyes, bracing myself for the blow. It comes hard, snapping across my backside, and the bite of the belt is everything I feared. I cry out involuntarily, and take a huge gulp of air.

"Count, Anastasia!" he commands.

"One!" I shout at him, and it sounds like an expletive.

He hits me again, and the pain pulses and echoes along the line of the belt. Holy shit... that smarts.

"Two!" I scream. It feels so good to scream.

His breathing is ragged and harsh. Whereas mine is almost non-existent as I desperately scrabble around my psyche looking for some internal strength. The belt cuts into my flesh again.

"Three!" Tears spring unwelcome into my eyes. Jeez - this is harder than I thought - so much harder than the spanking. He's not holding anything back.

"Four!" I yell as the belt bites me again, and now the tears are streaming down my face. I don't want to cry. It angers me that I am crying. He hits me again.

"Five." My voice is more a choked, strangled sob, and in this moment, I think I hate him. One more, I can do one more. My backside feels as if it's on fire.

"Six," I whisper as the blistering pain cuts across me again, and I hear him drop the belt behind me, and he's pulling me into his arms, all breathless and compassionate... and I want none of him.

"Let go... no..." And I find myself struggling out his grasp, pushing him away. Fighting him.

"Don't touch me!" I hiss. I straighten and stare at him, and he's watching me as if I might bolt, gray eyes wide, bemused. I dash the tears angrily out of my eyes with the backs of my hands, glaring at him.
"This is what you really like? Me, like this?" I use the sleeve of the bathrobe to wipe my nose.

(James, E.L, 2011:350)

The event above shown psysical exploitation, it happens when Christian Grey torture her by his belt and ask her to count then he hit her.

From events above researcher knows if Christian Grey tend to exploit his couple by physic and psychogy. It happens for his ways to forcing his desire and isolating woman from public, it is supported by "physical violance commited by using limb of the suspect or by using tools and psychologycal violance commited by insulting, threatening in order to force his desire and isolating woman from public (Hadi Saptiawan, 2007: 173). So, it means Christian Grey exploit her for forcing his desire and isolate his couple from public.

Based on theory about masculinism and masculnism events in the novel, the researcher will find events in society to prove those events are exist as culture in society, there are articles in below that explains events which exist in society that has similarity with events in the novel:

According to a news in www.cbsnews.com entitled "Rihanna opens up about Chris Brown assault in new candid interview" that is written by Lauren Moraski. In 2009, Rihanna as American singer felt assaulted by Chris Brown who is her 
boyfriend that is also an American singer. She said "I was that girl -- that girl who felt that as much pain as this relationship is, maybe some people are built stronger than others,". Based on her statement, she felt exploitation practice in relationship that did with her boyfriend which can causes physical and psychological pain. He is also given bad example to his fans about doing relationship, his action to Rihanna may happen to other people specially to his fans because that individual copy the behavior of their idol.

Second event, according to news in www.dailymail.co.uk entitled "Jimmy Kimmel Live! Comedian Beth Stelling reveals the abuse she suffered at the hands of her ex and shares photos of bruised legs" which is written by Snejana Farberov tells about abusing relationship between Beth Stelling who is a comedian with her ex-boyfriend. She said "It's embarrassing. I feel stupid. After being verbally, physically abused and raped, I dated him for two more months. It's not simple". Based on her statement, she felt something same as Rihanna that they feeling physical and psychological pain.

Third event is a news about women exploitation felt on a 17 years old girl names Sophie Parker that is got a punch from her boyfriend. It is reported by www.mirror.co.uk entitled "I thought it was normal for him to be so angry': Teenage victim of domestic abuse tells her story" that is written by Boudicca Fox-Leonard. She says "I had no idea what domestic violence was, and as I became isolated from my friends and family, I accepted his behavior as commonplace" from her statement, she is actually does not understand about the situation that she felt violence from people she loves, it is can cause sustainable violence for her.

The last event is according to an article entitled "Constructing Masculinity in Response to Women's Sexual Advances" that is written by Jennifer Lara Fagenand Peter B. Anderson which is the subject about men who reported unwanted sexual experiences with women as adults. They found result if “Most participants' experiences did not fall under the rubric of what is traditionally defined as sexual aggression. Even in those cases where some level of force was used by women to obtain sexual contact, a majority of participants described feeling powerful during their sexual encounters then some participants played the sexual gatekeeper role for their own amusement. They enjoyed the power and control associated with knowing that women would provide sexual favors for them while refusing to sexually gratify these women in return. These men seemed to feel comfortable with their masculinity as they were able to be flexible in this identity (2007: 264)". So, it means sexual exploitation that a 
man does also has purpose to get pleasure in it.

Those events can be a culture in society because as a public figure they have many fans that concern every attitude and behavior from their idol, for common people either in society if they are do not understand about these practices that will become trouble in psychology, physic or financial for them. There are similarity between primary data and secondary data which happens to Christian Grey, Celebrities and common person. The reason they do those actsis to grant their desire and isolate their couple from public as explained before.

\section{Results}

According to analyzes above researcher found there are three categories in masculinism, those are behavior, characteristics of masculinist, and exploitation in masculinism. Those categories appear in of Christian Grey, then researcher found similarity between the events in the novel with events in society related with theory. That means events in novel Fifty Shades of Grey really exist in society as culture because culture is human though, product, and action.

\section{Conclusion}

After completing the research, the researcher gives the conlcusion of those answer toward the research question. The conclusion are :
1. The events in novel Fifty Shades of Grey show masculinism practice between Christian Grey and Anastasia Steel. The masculinism practice is devided into three categories those are : (1) The behavior of masculinist. (2) The characteristics of masculinist (3) The exploitation in masculinism. Those practice happens by the way of their relationship, Christian Grey as the dominant like to control and exploit Anastasia steel as Submissive, so Anastasia Steel feels psycal and Psychologycal pain. It happens because Christian Grey want to force his desire and isolate Anastasia Steell from public by using his rules that is written in the contract.

2. Masculinism practice that Christian Grey does has similarity with events in society. Then, researcher found the events in the novel and society has purpose or reason. The purpose or reason of the events are relevant. (1) The behavior of masculinist has purpose to show care, interest and loves to woman. (2) The characteristics of masculinist has purpose to express their feeling toward their couple. (3) The exploitation of masculinism has purpose to force their desire and isolate their woman from public.

\section{References}

Book source: 
Ary, Jacobs, Sorensen and Razavieh.(2010). Introduction to Research in Education. $\left(8^{\text {th }} \mathrm{ed}\right) . \quad$ Belmont: Wadsworth Cengage Learning.

Belfort Bax. (1913). The Fraud of Feminism. London: Grant Richard LTD.

Borreli and Janet. (1997). The Other Elites; Women, Politics, and Power in The Executive Branch. ( $1^{\text {th }}$ ed). UK: Lynne Rienner Inc.

Creswell, John W. (2009). Research Design; Qualitative, Quantitative, and Mixed Method Approaches. USA: SAGE Publication Inc.

Fattah Hanurawan. (2010). PsikologiSosial. Bandung: PT RemajaRosdakarya.

Gans, Helbert J. (1974). Popular Culture and High Culture. New York: Basic Books Inc.

Ida RochaniAdi. (2010). FiksiPopuler: TeoridanMetodeKajian. Yogyakarta: PustakaPelajar.

James, E, L. (2011). Fifty Shades of Grey. USA: The Writer's Coffee Shop Publishing House.

Koentjaraningrat.(2002).

PengantarIlmuAntropologi. Jakarta: RinekaCipta.

Kothari, C. R. (2004). Research Methodology: Method and Technique.( $\left.1^{\text {sted }}\right)$. New Delhi: New Age International.

Marchbank, Jeniffer and Letherby, Gayle. (2007). Introduction to Gender: Social Science Perspective. Edinburgh: Pearson Education Limited.
SugihastutiltsnaHadiSaptiawan. (2007). Gender \&InferioritasPerempuan. Yogyakarta: PustakaPelajar.

Tan, Y., Shaw, P., Cheng, H., \& Kim, K. K. (2013).The construction of masculinity: A cross-cultural analysis of men's lifestyle magazine advertisements. Sex Roles, 69(5-6), 237-249. doi:http://dx.doi.org/10.1007/s11199013-0300-5

Fagen, J. L., \& Anderson, P. B. (2012).Constructing masculinity in response to women's sexual advances. Archives of Sexual Behavior, 41(1), 26170.doi:http://dx.doi.org/10.1007/s105 08-011-9851-0

Internet Source:

Devi, Asmarani. 2015. Ten Ways You're Wrong About Feminism, (online), (http://magdalene.co/news-380-tenthings-you're-wrong-aboutfeminism.html)

Farberov, Snejana. 2015. Jimmy Kimmel Live! comedian Beth Stelling reveals the abuse she suffered at the hands of her ex and shares photos of bruised legs, (online), (http://www.dailymail.co.uk/news/arti cle-3377621/Beth-Stelling-speaksabusive-past-relationship-sharesphotos-bruised-legs-candidInstagram-post.html.)

Leonard, Boudicca Fox. 2013. 'I thought it was normal for him to be so angry': Teenage victim of domestic abuse tells her story. (Online), (http://www.mirror.co.uk/news/reallife-stories/teenage-victim-domesticabuse-tells-1745667) 
Moraski, Lauren. 2015. Rihanna opens up about Chris Brown assault in new candid interview, (online), (http://www.cbsnews.com/news/rihan na-opens-up-about-chris-brownassault-in-new-candid-interview)

Sims, Andrew. 2014. 'Fifty Shades' sells 100 million copies, joining 'Potter' and 'Twilight' in achievement, (online), (http://www.hypable.com/fiftyshades-of-grey-book-sales-numbers)

Williams, Kali. 2012. 4 Reasons Why '50 Shades' Is Still So Popular, (online), (http://www.yourtango.com/experts/k ali-williams/why-has-fifty-shadesbeen-so-popular) 